\title{
Journal of Teacher Education
}

http://jte.sagepub.com

\section{Teacher Learning: the Key to Educational Reform \\ Ann Lieberman and Désirée H. Pointer Mace \\ Journal of Teacher Education 2008; 59; 226 \\ DOI: $10.1177 / 0022487108317020$}

The online version of this article can be found at: http://jte.sagepub.com/cgi/content/abstract/59/3/226

\author{
Published by: \\ (S)SAE \\ http://www.sagepublications.com \\ On behalf of:

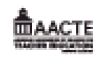 \\ American Association of Colleges for Teacher Education (AACTE) \\ Additional services and information for Journal of Teacher Education can be found at: \\ Email Alerts: http://jte.sagepub.com/cgi/alerts \\ Subscriptions: http://jte.sagepub.com/subscriptions \\ Reprints: http://www.sagepub.com/journalsReprints.nav \\ Permissions: http://www.sagepub.com/journalsPermissions.nav \\ Citations http://jte.sagepub.com/cgi/content/refs/59/3/226
}




\title{
TEACHER LEARNING: THE KEY TO EDUCATIONAL REFORM
}

\author{
Ann Lieberman \\ Désirée H. Pointer Mace \\ The Carnegie Foundation for the Advancement of Teaching
}

This letter to the next president of the United States recommends the transformation of teacher inservice learning as a powerful means of education reform. Too often, professional development is perceived by teachers as being idiosyncratic and irrelevant. The authors recommend a reconceptualization of professional learning for practicing teachers, in which educators are involved in learning communities, these communities evolve over time, and they revolve around norms of openness, scholarly rigor, and collaborative construction of professional knowledge. The authors describe three such environments of professional learning - the National Writing Project, the Carnegie Academy for the Scholarship of Teaching and Learning, and the Quest Project for Signature Pedagogies in Teacher Education-and recommend that the incoming chief executive should capitalize on the strengths of such programs and extend them to many more teachers nationwide.

Keywords: teacher learning; communities of practice; professional development; online networks

\section{Dear New President:}

We want to write to you about the importance of teacher learning, showing you what we have now, which hasn't been working too well, and giving you some important examples that we believe can show the wave of the future. This is an area of critical concern that needs your attention and support.

Teachers are on the front lines of a changing society. Teaching as telling is no longer appropriate for a knowledge society that needs students who are prepared in problem solving, adaptability, critical thinking, and digital literacies, just to name a few. These changing stakes are accompanied by changing demographics. Public schools now serve increasingly diverse student populations and schools and their teachers are being challenged to respond. Teachers work in isolation and only rarely have a chance to observe their colleagues or talk about their teaching work. Although many agreed on the purposes of No Child Left Behind
(NCLB), its implementation has fallen short of expectations by reducing accomplished teachers' opportunities to draw on the wisdom of their experiences to serve their students. Student learning needs improvement; teacher knowledge seems to be one answer. But how to get there is the crux of the problem.

\section{WHAT IS THE PROBLEM?}

One natural solution is to teach teachers how to improve their practice. But professional development, though well intentioned, is often perceived by teachers as fragmented, disconnected, and irrelevant to the real problems of classroom practice. Less than half of National Board-certified teachers are satisfied with the quality and quantity of professional learning opportunities available at their school (Leadership Survey; National Board for Professional Teaching Standards, 2001). This finding is echoed by the MetLife Survey of the American Teacher 
(Metropolitan Life/Harris Interactive, 2003): Only $42 \%$ of teachers surveyed in their study of school leadership felt that their principals provided adequate professional development opportunities. Most professional development simply misses the mark.

\section{WHAT IS KNOWN ABOUT PROFESSIONAL DEVELOPMENT FOR TEACHERS?}

NCLB now dominates professional development in many schools. In a typical school, all teachers go to professional development workshops where they most often learn how to follow a script that presumably they will use in hopes of raising their students test scores. This approach ignores the different needs of the students, the experience of the teacher, and the myriad possibilities for engaging students in learning. In most schools, teachers are asked to use a curriculum package regardless of the context that has caused demoralization in many schools, shrinking the curriculum and taking away all the necessary judgments of the teacher as to the appropriateness of the content for their particular students.

Instead of building a culture of professional learning, teachers are faced with a "culture of compliance." Instead of learning from and with their fellow teachers as well as learning from research, teachers are being given a script that tightly binds them to a narrow curriculum that may or may not fit the needs of the teachers or their particular classrooms. Instead of creating the conditions for teachers to teach each other, support their peers, and deepen their knowledge about their students, teachers are being given a "one size fits all" set of professional development workshops that deny the variability of how teachers teach, and how they and their students learn. But there is much that we are learning that can help us frame this problem differently and much that you can do as president to enable and support a different way of thinking about professional development.

\section{CREATING A SOCIAL CONTEXT FOR LEARNING}

There has been a burgeoning of both research and experience teaching us to move in a different direction with more long-lasting results and a deeper understanding of the kinds of conditions needed to improve teachers' practice (see, e.g., Cochran-Smith \& Lytle, 1993; Lieberman \& Wood, 2003; McLaughlin \& Talbert 2006; Wenger, 1998).

We are coming to understand that learning rather than being solely individual (as we have taken it to be) is actually also social. It happens through experience and practice. In plain terms-people learn from and with others in particular ways. They learn through practice (learning as doing), through meaning (learning as intentional), through community (learning as participating and being with others), and through identity (learning as changing who we are). Professional learning so constructed is rooted in the human need to feel a sense of belonging and of making a contribution to a community where experience and knowledge function as part of community property. Teachers' professional development should be refocused on the building of learning communities. It is this understanding, along with some important shifts toward studying teachers' practice, that have helped focus teachers' professional development on the building of learning communities. It is this turn that we think should be a big part of your approach to supporting professional development. We believe that districts and states can support professional learning communities by providing teachers with continuous blocks of time devoted to a variety of ways for teachers to teach teachers the strategies that have been successful with their own students, using technology to illustrate good teaching, and building networks of teacher communities where teacher leaders can provide such professional development with their colleagues. The National Writing Project (NWP), which you already support, is an excellent example of what we mean (Lieberman \& Wood, 2003).

\section{GETTING INSIDE TEACHER COMMUNITIES}

There is now a great deal of evidence that teachers learn best when they are members of a learning community and there is some beginning knowledge their students do also (see, 
e.g., Grossman, Wineburg, \& Woolworth, 2001; Little, in press; McLaughlin \& Talbert, 2001; Stoll \& Louis, 2007; Supovitz \& Christman, 2003; Westheimer, 1998).

Looking at two different middle schoolsBrandeis and Mills-both with a reputation of being professional learning committees, Westheimer (1998) gathered the nuances that help explain the subtleties in teacher communities. He described the enormous differences in the goals, structures, processes, and beliefs of these communities and how these differences are manifested in the character of the two schools. The analysis of Brandeis and Mills begins to add important details of practice to the theories of community. For example, they both had shared beliefs; however, Brandeis's teaching strategies were "individualized dependent on teacher's choice," whereas Mills's are "collectivized, interdisciplinary, and project based" (p. 121). These differences are manifested in a variety of other ways as well. At Brandeis, administrators make decisions without input from teachers, participation in public forums is limited, and professional and personal commitments are often in conflict. At Mills, teachers make decisions and set school policy, participation is widespread and extensive, and professional work is highly social and engages people through personal and social commitments (p. 123). These differences turn out to be important as they demonstrate that communities can be individual or collaborative, highly autonomous or collective, and traditionally led or led by teachers. And both can be professional communities.

McLaughlin and Talbert (2006) have been studying school-based learning communities for more than 15 years. Their seminal work has taught us that school-based communities are uniquely situated between "macro-" or system-level directives and resources and the "micro"realities of teachers' classrooms. They argued that school-based communities manage "from the middle," and in so doing they can successfully negotiate the policy demands at the top and their local situation at the bottom (p. 4). Because these communities can be found on grade-level teams, within departments, or even in a whole school faculty, they can help build a shared language and a way of working that is consonant with their school's local context and culture. But learning communities in schools appear to often need external resources to support internal work; to provide different expectations for teaching and learning; and opportunities to practice different roles, responsibilities, and relationships. It is here that you as president can encourage and support the creation of these "learning communities." As president you can support the expectation that teachers will participate in communities at their school, provide money for time over the year to meet, and encourage the growth of teacher leadership to extend and expand professional development.

\section{NETWORKS AND PARTNERSHIPS SUPPORT TEACHER LEARNING AND LEADERSHIP}

A number of reform networks, schooluniversity partnerships, and coalitions have formed in the last few decades-many creating opportunities for teachers to learn from and with their colleagues (Lieberman, 1992; Lieberman \& Grolnick, 1996; McDonald, Mohr, Dichter, \& McDonald, 1999). But arguably, none has lasted as long and produced so many graduates as the NWP - and, most important, none has been able to "scale up" the way the NWP has. To date, there are now 200 sites. ${ }^{1}$ Recently a study documented the influences of the NWP on teachers who had been in the writing project from 1974 to 1994 - the first 20 years of the NWP. The study found that writing project experiences influenced their work at all levels of the educational system (Lemahieu, Swain, Fessehaie, \& Mieles, 2007). In addition to these studies, Lieberman and Wood (2003) documented the summer institute in an urban and a rural site. They then followed four teachers back to their classrooms to see if what they learned in the summer institute ever found its way into their classrooms. They found that all four teachers were using many of the strategies that they learned in the summer institute and, of importance, that there was a set of social practices that provided the core processes that went on during the institute. These practices are replicated in the 200 existing sites to date. 
Perhaps this gives us one of the clues as to the importance of external networks. The NWP has shown us not only how to engage teachers professionally but also how to involve them in a community that cares about them, their learning, and their continuous growth. In addition to these practices, after the summer institute many teachers are asked to become teacher consultantsprofessional developers who facilitate learning for others. In sum, the NWP provides some important understandings about how to engage and motivate teachers, how to form learning communities, and how to develop leadership among its participants. They have provided evidence that the greater the teacher learning, the more students learn as well. As president, you can continue to fund such groups as the NWP as they have already proven that they can support not only better teaching but also increased student learning.

Another important developmental effort that has been documented has been that of the networked communities in the United Kingdom (Jackson, 2006; Jackson \& Temperley, 2007). In that effort, the authors describe a 5-year project sponsored by the government in which teachers worked in a partnership arrangement with one or more schools forming a variety of networks to enhance the quality of student learning. In so doing, they changed the nature of professional development in supporting school-to-school learning. In each of the groups of schools, joint work groups were formed; they planned collectively, developed problem-solving teams, and shared professional development activities. The school networks helped to create practitioner knowledge (from teachers' experience), public knowledge (from research and theory), and new knowledge (from what was created together). During the 5 years, not only did teacher engagement in communities (more than 150) involve hundreds of teachers throughout the United Kingdom, but their students' learning improved. In an evaluation of the effort, three findings are significant. These networks of teachers from different schools managed to raise achievement for students, taught the participants how to work collaboratively linked to "rigorous and challenging joint work," and managed to build trust in helping make teaching public as they developed and distributed leadership among the teachers (Earl, Katz, et al., 2006).

These two examples show how teachers are developed in a community and learn how to facilitate learning for others. They teach us how, and in what ways, teachers taken out of their immediate school community become socialized into a collaborative culture and more attuned to the complexity and ambiguity of their classroom work. They teach teachers to trust and learn from one another. Both learning communities in schools and networks across schools turn out to be an important and viable way of thinking differently about professional development.

\section{Learning and Teaching}

A number of reform networks have become increasingly self-conscious about what they are learning and how resources can be used to support teacher learning. For example the Networked Communities (http://www.nlcexchange.org.uk) has created many tools and templates for teachers. These publications range from What Does a Network Leader Do? to Getting Started With Networked Research Lesson Study. As the school networks grew, the organizing group continued to put out publications that helped to guide the various school networks in their improvement efforts. In like manner, the Coalition of Essential Schools invented meeting tools that helped participants learn to talk with one another, build trust, and help people discuss teaching practice. In particular, they introduced the power of protocols (McDonald et al., 2007) and how to focus on looking at student work (Allen \& Blythe, 2004). These materials are now used by networks and partnerships all over the country, helping teachers learn a new way of being with their peers, increasing their ability to talk publicly about their practice, and improving their teaching by working with their colleagues. As a new president, I think you can see that by turning professional development toward the building of learning communities for teachers, providing for variety and collaboration rather than uniformity and conformity, and putting teacher 
knowledge at the center instead of curriculum packages, you will be supporting a culture of professionalism rather than a "culture of conformity." Our examples that follow show you how these kinds of communities can be supported and developed.

\section{How We Have Worked to Develop Teacher Learning: A Tale of Three Communities}

Experienced teachers know that teaching and learning are complicated, layered enterprises. But too often policy discussions of teaching are reductive rather than expansive, leading to analysis of aggregated test data instead of rich discussions about ways to move the wisdom of practice from classroom to classroom. Over the past decade, we have worked with several cohort communities in projects of the Carnegie Foundation for the Advancement of Teaching involved in developing K-12 teachers' learning and knowledge. Three different models of teacher learning communities have developed: One grew out of teachers' own questions about their practice, one deliberately engaged K-12 teachers and professors of teacher education in "going public" with multimedia records of their practice, and one traced the process of teachers adapting what they learned from professional development into their own classroom contexts.

Our work has placed more emphasis on "going public" with teacher knowledge than on studying learning outcomes for students. Still to be accomplished is linking the growth of the use of these records of teaching practices to student learning outcomes. These records of teaching practices pave the way for enriched conversations about the complexities of student learning. Getting underneath the students' test scores to investigate their understandings of content over time, in interaction with their instructors, more closely approaches the sophistication and complexity with which accomplished teachers assess their students' learning. We have every reason to believe that a "culture of craftsmanship" seen in high-quality professional development, as described earlier, will be positively connected to improved student learning.

\section{LEARNING FROM TEACHERS' QUESTIONS: THE CARNEGIE ACADEMY OF THE SCHOLARSHIP OF TEACHING AND LEARNING (CASTL), 1999-2004}

The CASTL project consisted of several cohorts of K-12 faculty from around the country who were brought together for a period between 1 and 2 years to develop the scholarship of their teaching practice. According to Shulman (1999), the teaching profession suffers from a lack of a scholarly tradition, especially when compared with professional and disciplinary learning in the sciences, law, and medicine. If they are to learn from the expertise in their ranks, teachers must make their inquiry into their teaching practice public, invite others to provide critique, and then build on their own and others' work to elevate the knowledge base of teaching professionals. In the CASTL project, however, we quickly observed that because of the relational nature of teaching practice, it was more difficult to adequately describe the multilayered nature of teachers' questions, contexts, and evolving practice over time in only one medium. Many of the CASTL scholars began to work with us to create multimedia Web sites to share their questions and reflections as well as videos of classroom practice, examples of student work, and the teachers' pedagogical and curriculum materials (Hatch et al., 2005; Hatch \& Pointer Mace, 2007; Pointer, 2003; Pointer, Hatch, \& Iiyoshi, 2002).

In the CASTL project, the community was formed around the exchange of the teachers' scholarship; evolved over 1 to 2 years, combining in-person assemblies with electronic asynchronous communication; and culminated in the publication of the fellows' work, variously online (in the Gallery of the Scholarship of Teaching and Learning, http:/ / gallery.carnegiefoundation.org), in educational journals (e.g., Cone, 2003), or in books (e.g., Berger, 2003). Over time, allies of the CASTL project who worked in teacher education settings began to experiment with using the Web sites as alternative texts for the preparation of novice teachers. Pam Grossman of Stanford University, Anna Richert of Mills College, and Kathy Schultz of the University of Pennsylvania began experimenting with what 
it would mean to use Web sites as "texts" in their courses, what new literacies would be required to "read" practice, and how the sites could connect with other "signature pedagogies" (Shulman, 2005) of teacher education such as case analysis and student teaching field placements. We realized that by bringing these two communities together-accomplished teachers and innovative teacher educatorswe might be able to significantly transform the transmission of the "wisdom of practice" (Shulman, 2004) in learning to teach.

\section{LEARNING FROM RECORDS OF PRACTICE: THE QUEST PROJECT FOR SIGNATURE PEDAGOGIES IN TEACHER EDUCATION, 2004-2006}

Jointly funded by the Richard and Rhoda Goldman Fund and the Carnegie Foundation, the Quest Project brought together accomplished teachers in K-12 classrooms with a national cohort of professors of teacher education to create additional multimedia Web sites of $\mathrm{K}-12$ teaching practice, mindfully integrate them into a diverse array of teacher education settings, and document teacher educators' processes of teaching with these new "texts." In this case, the Web sites not only originated from the individual practitioners' questions and observations but were intended to respond to particular gaps and dilemmas of teacher education: teaching high school English teachers how to run an effective discussion of literary texts, showing elementary math teachers how to carefully pose problems for mathematical understanding, and showing how to help secondary teachers understand not only their content matter but the developmental considerations involved in teaching adolescents, just to name a few.

In the Quest Project, the K-12 and teacher education cohorts did not convene in a large group together; rather, this extended community exchanged ideas around the development of the Web sites. As the K-12 and teacher educators documented their teaching, they made draft versions of their Web sites public so that interested colleagues could ask questions, request relevant related materials, and problematize any contentious sections. The whole group saw themselves as teachers and learners; in fact, many of the teacher educators learned a great deal from their more techno-savvy students as they began to experiment with new technologies in their teaching. Because the community was organized around the creation and exchange of multimedia records of practice, its culminating experience was the launch of a "living archive" of teaching practice (http:/ / www .InsideTeaching.org), which brought together the individual practitioner Web sites, perspectives on their use for teacher learning, related resources and initiatives, and tools for creating new multimedia Web sites of teaching practice.

Prior to the public launch of InsideTeaching .org, however, something interesting began to happen with one of the K-12 Web sites. The project team started receiving dozens of unsolicited e-mails in response to Jennifer Myers's Web site about her practice of readers and writers workshop in her second-grade classroom. The e-mails, mostly from practicing teachers but a few from teacher educators or school principals, were uniformly appreciative of Myers's opening up her classroom practice for others to learn from and with. One teacher applauded her bravery in making her teaching public:

I think it is really brave of you to put yourself out there like this so that many ofthe rest of us can "peek" inside your classroom. One of the worst things about teaching is that they never give you enough time to observe in other classrooms ONCE you become a teacher. You get lots of time when you are a student teacher, but after you've taught for several years, that's when you know what to look for and what you need to reinvigorate your classroom.

Another wrote that she "found the website extremely helpful. Currently, I am in a credentialing program and was very pleased to find this site. It has served to clarify confusion about how a Reader's Workshop is conducted." An international teacher from Chang Mai, Thailand wrote that she

stumbled across your website this afternoon while preparing for a teachers training on reading and writing workshops. I can't believe that you are such a new teacher! After only a few years you have 
really got it down! Bravo! . . . I am doing a teacher training when school starts. We have graduated from three teachers to five this coming year and as the 5th grade teacher I am hoping to get everyone "on the same page" so that by time the kids get to me they have some basic skills. Until now it has been every man for himself as far as teaching methods and strategies. Not working, believe me! Sadly, I had a group of 5 th graders this year who read 2 nd grade level and can't write a sentence let alone a paragraph or story. They had never really written stories if you can believe it! Anyway, if you wouldn't mind I would like to show your videos to my teachers during our training. They are wonderfully done and so easy to follow.

After responding to these e-mails (and many others) we learned that the teachers were coming upon Myers's site after entering "writing workshop videos" into their search engines. By chance, Jennifer Myers's site tapped into a felt need in the teaching community writ large-to see into the practices of literacy workshop, to unpack them, and to translate them to other teaching contexts. Myers herself describes on her Web site that her workshop approach to literacy has been greatly influenced by her experiences in professional development run by Every Child a Reader and Writer (ECRW), a project funded by the Noyce Foundation. We shared Myers's site and the e-mail responses with Noyce, and together we began to think about what it might look like to capture the process of transmission of knowledge for inservice teachers, to document the practice of professional development (and a professional developer) and several teachers' work to transform the Noyce literacy and writing workshop practices into their local settings.

\section{THE NOYCE-CARNEGIE QUEST PROJECT FOR ELEMENTARY WRITING WORKSHOP: 2006-2007}

In June 2007, we completed a yearlong initiative to document this transmission of the "wisdom of practice" for experienced practicing teachers in the teaching of writing. For the first time, because the teachers involved had structured their literacy instructional time in parallel ways according to the Noyce model of writing workshop, we were able to create one
Web site for multiple practitioners, centered around a visual matrix allowing audiences to follow not only the teaching, materials, and reflections of individual teachers but also particular practices across grade levels in multiple settings. Audiences hungry for examples of different educators' approaches to the teaching of writing can follow how four teachers (grades $\mathrm{K}, 2$, 2, and 5) open the writing workshop, confer with their students, provide independent time for students to develop their writing, and celebrate the works generated at the end of the workshop period.

The Noyce Foundation prioritizes an impact on local schools for ECRW, but this "Web site of Web sites" allows audiences far beyond the ECRW implementation school districts access to these professional learning opportunities. Contrary to professional development models predicated on "best practice," this project rests on the assertion that there can be multiple ways to translate strong ideas about literacy teaching into particular classroom contexts. Teaching is inherently variable, but that does not mean that the practices are weakened by variability. By contrast, a recognition that professional learning opportunities should adapt to particular contexts, student populations, and developmental levels will give the practices themselves more traction and momentum.

Already the experienced teachers charged with maintaining momentum for ECRW in their local sites are thinking about ways to use the site for professional learning. One coach observed that the sites afford teachers the ability to "look out" (analyze the walls, charts, and instructional supports visible in the classroom) and "look in" (analyze the interactions between teacher and student in a writing conference). Another mentioned that showing examples of a school's literacy approach will greatly enhance communication with parents on Back to School nights. A principal observed that looking across examples of teacher learning would be strengthened even further by showing student development over time, if a group of teachers at a school site could commit to documenting their practice and making it public. Their response was strong-they see themselves as part of a burgeoning movement in which 
teacher learning and teacher knowledge moves from margin to center in the advancement of the profession.

\section{How Can We Reframe Professional Development and Teacher Learning?}

The teacher communities described here exhibit the best we know so far about effective professional development. They focus on instruction; are sustained and continuous, rather than short term and episodic; provide opportunities for teachers to learn from one another both inside and outside the school; make it possible for teachers to influence how and what they learn; and engage teachers in thinking about what they need to know (Hawley \& Valli, 2007). Whether organized as a group of teachers, a department, team, or a group of schools, the idea of teacher communities has been embraced by educators all over the world as a way of meeting the challenges of improving schools in this fast-changing global society. In addition, teachers are expanding their circle of like-minded colleagues by forming and joining online teaching communities, which allow geographically dispersed members to meet, exchange ideas, and learn from each other. Perhaps if we think of these learning communities as the best professional development for teachers, we can concentrate on offering supports that will encourage the communities to grow and, in the process, create the conditions for more open and collaborative school cultures.

\section{NOTES}

1. A site in the NWP grows out of a university-school partnership. The university is the "owner" of the site. Beginning sites receive \$20,000 and must document both their plans and their work throughout the year and keep accurate information on who they serve and the nature of the formats for work.

\section{REFERENCES}

Allen, D., \& Blythe, T. (2004). The facilitator's book of questions. New York: Teachers College Press.

Berger, R. (2003). An ethic of excellence: Building a culture of craftsmanship in schools. Portsmouth, NH: Heinemann.

Cochran-Smith, M., \& Lytle, S. (1993). Inside/outside: Teacher research and knowledge. New York: Teachers College Press.
Cone, J. (2003, May/June). The construction of low achievement: A study of one detracked senior English class [Online]. The Harvard Education Letter. Retrieved May 31, 2007, from http://www.edletter.org/past/ issues /2003-mj/teacher.shtml

Earl, L., Katz, S., Elgie, S., Ben Jaafar, S., \& Foster, L. (2006). How networked communities work. Final report of the three year External Evaluation of the Networked Learning Communities Programme. Nottingham, UK: National College of School Leadership.

Grossman, P., Wineburg, S., \& Woolworth, S. (2001). Toward a theory of teacher community. Teachers College Record, 103(6), 942-1012.

Hatch, T., Ahmed, R., Lieberman, A., Faigenbaum, D., Eiler White, M., \& Pointer Mace, D. (2005). Going public with our teaching: An anthology of practice. New York: Teachers College Press.

Hatch, T., \& Pointer Mace, D. (2007). Making teaching public: A digital exhibition. Teachers' College Record Online. Retrieved from http://www.tcrecord.org/ content.asp? contentid $=13462$

Hawley, W., \& Valli, L. (2007). Design principles for learner-centered professional development. In W. Hawley with D. Rollie (Eds.), The keys to effective schools: Educational reform as continuous improvement (2nd ed., pp. 117-137). Thousand Oaks, CA: Corwin.

Jackson, D. (2006, December). Networked learning communities: Setting school to school collaboration within a system context (Centre for Strategic Education Seminar Series Paper No. 159). Nottingham: National College for School Leadership.

Jackson, D., \& Temperley, J. (2007, January). From professional learning community to networked learning community. In L. Stoll \& K. S. Louis (Eds.), Professional learning communities: Divergence, depth and dilemmas (pp. 45-62). New York: Open University Press.

Lemahieu, P. G., Swain, S. S., Fessehaie, S., \& Mieles, T. (2007, April). Making a difference: NWP's inculcation of leadership over 30 years. Paper presented to the American Educational Research Association meeting, Chicago.

Lieberman, A. (1992). School-university partnerships: A view from the inside. Kappan, 74(2), 147-156.

Lieberman, A., \& Grolnick, M. (1996). Networks and reform in American education. Teachers College Record, 98(1), 8-45.

Lieberman, A., \& Wood, D. R. (2003). Inside the National Writing Project: Connecting network learning to classroom teaching. New York: Teachers College Press.

Little, J. W. (in press). Teachers' accounts of classroom experience as a resource for professional learning and instructional decision-making. In P. Moss (Ed.), Evidence and decision making. Chicago: University of Chicago Press.

McDonald, J., Mohr, N., Dichter, A., \& McDonald, E. C. (2007). The power of protocols (2nd ed.). New York: Teachers College Press.

McLaughlin, M. W., \& Talbert, J. (2001). Professional communities and the work of high school teaching. Chicago: University of Chicago Press. 
McLaughlin, M. W., \& Talbert, J. (2006). Building school-based teacher learning communities: Professional strategies to improve student achievement. New York: Teachers College Press.

Metropolitan Life/ Harris Interactive. (2003). Metlife Survey of the American Teacher. New York: Metropolitan Life.

National Board for ProfessionalTeaching Standards. (2001). Leading from the classroom: Highlights from the 2001 NBPTS National Board Certified Teacher Leadership Survey conducted by Yankclovtch Partners. Arlington, VA: NHITS. Available from www.nbpts.org

Pointer, D. (2003). What's in it for me? Opportunities and outcomes of using multimedia and the internet to represent and share practitioner research. Paper presented at the American Educational Research Association, Chicago.

Pointer, D., Hatch, T., \& Iiyoshi, T. (2002). What happens when teachers put inquiry online? Paper presented at the meeting of the American Association of Higher Education, Chicago.

Putnam, R., \& Borko, H. (1997). What do new views of knowledge and thinking have to say about research on teacher learning? Educational Researcher, 29(1), 4-15.

Shulman, L. (1999, July/August). Taking learning seriously. Change, 31, 10-17.

Shulman, L. (2004). The wisdom of practice: Essays on teaching, learning, and learning to teach (S. M. Wilson, Ed.). San Francisco: Jossey-Bass.

Shulman, L. (2005, February). The signature pedagogies of the professions of law, medicine, engineering, and the clergy: Potential lessons for the education of teachers. Presentation delivered at the Teacher Education for Effective Teaching and Learning workshop, National Research Council's Center for Education, Washington, DC.

Stoll, L. \& Louis, K. S. (2007). Professional learning communities divergence: Depth and dilemmas. Berkshire, UK: Open University Press.
Supovitz, J. A., \& Christman, J. B. (2003). Developing communities of instructional practice: Lessons from Cincinnati and Philadelphia (CPRE Policy Brief). Philadelphia: University of Pennsylvania.

Wenger, E. (1998). Communities of practice: Learning, meaning $\mathcal{E}$ identity. Cambridge, UK: Cambridge University Press.

Westheimer, J. (1998). Among schoolteachers: Community, autonomy and ideology in teachers' work. New York: Teachers College Press.

Ann Lieberman is an emeritus professor from Teachers College. Her research interests have been on networks and on partnerships that are organized to create the conditions for enhanced teacher learning and the development of teacher knowledge. She has written or edited more than 15 books; her best known work is a book, written with Lynne Miller, titled Teachers: Their World and Their Work. She is now a senior scholar at the Carnegie Foundation for the Advancement of Teaching.

Désirée H. Pointer Mace is an assistant professor in the School of Education at Alverno College. Her teaching and research interests include the creation and use of multimedia records of teaching practice in environments of teacher learning. With Ann Lieberman, she previously codirected the Quest Project for Signature Pedagogies in Teacher Education at the Carnegie Foundation for the Advancement of Teaching. She taught for several years as an early primary Spanish bilingual elementary school teacher in Oakland and San Francisco Unified School Districts. 